\title{
Elevated Levels of DNA Strand Breaks Induced by a Base Analog in the Human Cell Line with the P32T ITPA Variant
}

\author{
Irina S.-R. Waisertreiger, ${ }^{1,2}$ Miriam R. Menezes, ${ }^{1}$ James Randazzo, ${ }^{3}$ and Youri I. Pavlov ${ }^{1}$ \\ ${ }^{1}$ Eppley Institute for Research in Cancer, University of Nebraska Medical Center, Omaha, NE 68198-6805, USA \\ ${ }^{2}$ Institute of Cytology, Russian Academy of Sciences, St. Petersburg 194064, Russia \\ ${ }^{3}$ Department of Pharmaceutical Sciences, University of Nebraska Medical Center, Omaha, NE 68198-6025, USA \\ Correspondence should be addressed to Youri I. Pavlov, ypavlov@unmc.edu
}

Received 26 April 2010; Accepted 11 July 2010

Academic Editor: Ashis Basu

Copyright (C 2010 Irina S.-R. Waisertreiger et al. This is an open access article distributed under the Creative Commons Attribution License, which permits unrestricted use, distribution, and reproduction in any medium, provided the original work is properly cited.

\begin{abstract}
Base analogs are powerful antimetabolites and dangerous mutagens generated endogenously by oxidative stress, inflammation, and aberrant nucleotide biosynthesis. Human inosine triphosphate pyrophosphatase (ITPA) hydrolyzes triphosphates of noncanonical purine bases (i.e., ITP, dITP, XTP, dXTP, or their mimic: 6-hydroxyaminopurine (HAP) deoxynucleoside triphosphate) and thus regulates nucleotide pools and protects cells from DNA damage. We demonstrate that the model purine base analog HAP induces DNA breaks in human cells and leads to elevation of levels of ITPA. A human polymorphic allele of the ITPA, 94C->A encodes for the enzyme with a P32T amino-acid change and leads to accumulation of nonhydrolyzed ITP. The polymorphism has been associated with adverse reaction to purine base-analog drugs. The level of both spontaneous and HAP-induced DNA breaks is elevated in the cell line with the ITPA P32T variant. The results suggested that human ITPA plays a pivotal role in the protection of DNA from noncanonical purine base analogs.
\end{abstract}

\section{Introduction}

Modified bases in DNA pose a severe threat for genome integrity [1], (Figure 1). DNA could be directly damaged by environmental factors such as ionizing radiation, chemical mutagens or endogenous factors, such as oxidative stress and inflammation [2-4]. Many of these factors also damage nucleotides in DNA precursor pools [5-7]. Additionally, cellular metabolism per se also contributes to the contamination of pools by nucleobase-analogs. Base-analogs in the deoxyribonucleoside triphosphate form are incorporated into DNA by DNA polymerases and are the source of genetic changes [8]. Potent repair systems remove not only the lesions from DNA, but also the harmful triphosphates from the DNA precursor pools (Figure 1, $[1,8]$ ). Defects of these protection mechanisms lead to hypermutagenesis [9] or hyperrecombination [10-12] and result in genome instability, which predisposes individuals to diseases like cancer $[13,14]$. Base-analogs are clinically important and are widely used as immunosuppressants as well, antiviral and anticancer agents. The determination of the reasons for individual sensitivity/resistance is of high priority.

The major mutagenic modified purine bases include 8oxoguanine and 2-hydroxyadenine [15]. The 8-oxoguanine in deoxyribonucleoside triphosphate form can be incorporated into DNA by replicative as well as specialized DNA polymerases [16-18]. It can form base pairs with cytosine and adenine and, therefore, can lead to transversion mutations [19]. The MutT protein of E. coli hydrolyzes 8-oxodGTP to 8-oxodGMP, preventing incorporation into DNA [17]. Mutational inactivation of this gene leads to a 10.000-fold increase in the rates of transversions [20], but no elevation of DNA fragmentation is detected in mut T strains [21]. The 2-hydroxyadenine also has strong mutagenic potential [3]. Deamination of normal purines, as well as disregulation of the purine biosynthesis, leads to contamination of nucleotide pools with deoxyinosine triphosphate and deoxyxanthine triphosphate. Inflammation induces various types of base damage from oxidative stress and elevated lipid peroxidation [22]. The latter can 
generate mutagenic derivatives of adenine and guanine, HAP and its 2-amino derivative in vitro [23]. HAP might be generated by monooxygenation of adenine [24]. HAP also can be generated by adenylosuccinate synthase, an enzyme of the de novo purine biosynthesis pathway wherein hydroxylamine is provided instead of aspartate in the reaction with IMP [25]. Thus, HAP can be a natural contaminant of dNTP pools $[23,26]$, however the literature does not report direct measurements of HAP derivatives in nucleotide pools. HAP is strongly mutagenic in bacteria and yeast $[26,27]$. The dHAPTP is incorporated into DNA by various DNA polymerases in vitro $[28,29]$. Overwhelming indirect genetic evidence in microorganisms suggests that the mutagenic effect is mediated by dHAPTP incorporation into DNA [26]. There is only fragmentary information about the effects of endogenous and exogenous base-analogs, such as HAP, in multicellular eukaryotes.

There are a number of evolutionarily conserved enzymatic systems that sanitize the nucleotide pool by selectively breaking deoxynucleoside triphosphate forms of base-analog DNA precursors, either to monophosphate $[17,30]$ or to nucleoside [31, 32] or diphosphate [33]. Additional systems affect quality of dNTP pools [34]. One of them, NUDT16, destroys abnormal diphosphates [35]. Polymorphisms in the genes encoding protective enzymes are associated with an increased risk of cancer [36], a predisposition to base-analogassociated adverse drug reactions [37] or a modulation of response to therapy in hepatitis $\mathrm{C}$ patients [38].

ITPA is a prominent enzyme protecting from baseanalogs [27, 39]. ITPA orthologs from humans, yeast (encoded by the HAM1 gene), and bacteria (encoded by the $r d g B$ gene) control levels of ITP, dITP and dHAPTP by hydrolyzing ITP/dITP to PPi and IMP/dIMP [27, 30, 40]. One report documents that yeast ITPA can hydrolyze pyrimidine analogs as well [41]. ITPA is highly conserved among species $[26,40,42]$. In $E$. coli, the $r d g B$ mutation is synthetically lethal with the $\operatorname{rec} A$ mutation abolishing homologous recombination $[27,39]$. The $r d g B$ mutation sensitizes to the mutagenic and recombinogenic effects of HAP in molybdenum-cofactor defective strain background (another system protecting from HAP [43-45]) because of a massive accumulation of breaks in DNA $[27,39,46]$. DNA damage is caused by intermediates in the repair of baseanalogs in DNA by Endo V encoded by the $n f i$ gene. This has been proven by the viability of triple $\operatorname{rdgB} \operatorname{rec} A$ nfi mutants [27].

HAP is very mutagenic in yeast but does not induce recombination [48]. A defect in the yeast homolog of ITPA, Ham1, leads to elevated HAPmutagenesis, but it does not affect spontaneous mutagenesis [49]. The natural substrate, dITP, seems to be non-mutagenic when it is incorporated in DNA, because hypoxanthine base pairs properly with cytosine [50], and yeast apparently do not possess an enzyme able to recognize hypoxanthine, xanthine and HAP in DNA similar to Endo V. Therefore, DNA with these bases is not nicked and no recombination and DNA breakage are seen. The situation in yeast might be atypical. Inosine and xanthine in DNA are recognized in most organisms by a specialized repair system initiated by the orthologs of

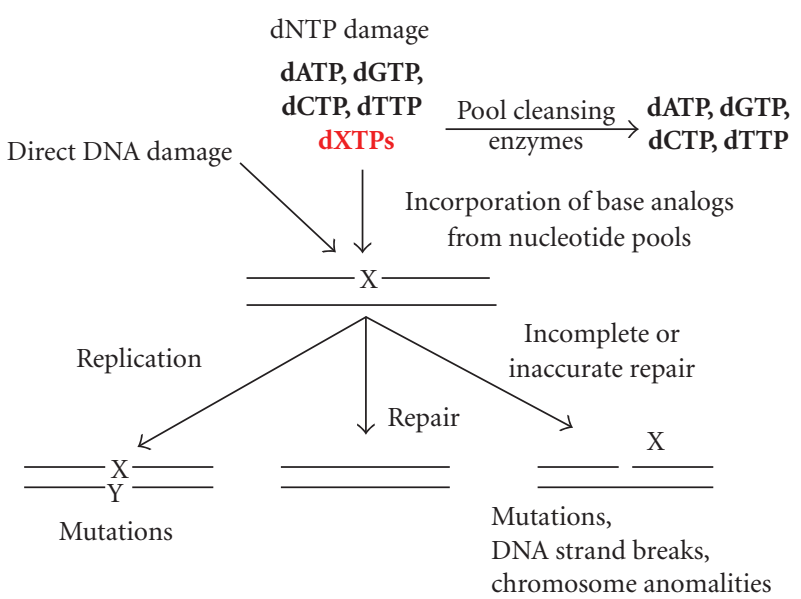

Figure 1: Base-analog DNA cycle. Environmental and intrinsic mutagens can damage DNA directly or can damage DNA precursor pools. When cleansing is inefficient, base-analogs are incorporated into DNA. Damaged bases lead to mutations in replication cycles or can be correctly repaired by base excision repair. Intermediates of this repair can lead to mutagenesis, DNA breaks, and chromosome changes.

endonuclease $\mathrm{V}$ [51] and elicit DNA repair reactions that lead to DNA fragmentation and genomic instability when the level of analogues is high $[3,39,46]$.

The repair of purine base-analogs in humans has not been studied. Mutations in the human ITPA gene lead to the accumulation of ITP in erythrocytes but do not show a clear disease phenotype, perhaps due to compensation by other cleansing enzymes [52, 53]. Human ITPA P32T variant, abolishing the ITPA activity in erythrocytes, has been associated in most publications with adverse reactions to purine analogues used in the treatment of blood cancers, transplant, and inflammatory bowel diseases [37, 54-59]. The ITPA P32T variant causes sensitivity to mercaptopurine used for the treatment of acute lymphoblastic leukemia [60].

Knockout of the Itpa gene in mice is lethal primarily because of heart failure [53]. Primary embryonic fibroblasts exhibit moderate chromosome instability phenotype [61], and the inviability of the Itpa knockout mice suggests that the enzyme performs essential functions in addition to the prevention of the misincorporation of purine base-analogs in DNA. If we assume that the role of ITPA is the same in humans, the ITPA P32T variant should result in an incomplete loss of activity, at least in the heart. Indeed, ITPA with the change possesses enzymatic activity but is thermally unstable $[62,63]$, suggesting a possibility that the levels of the protein and its activity could vary among tissues.

In this study, we demonstrate by comet assay that the model purine base-analog, HAP, induces DNA strand breaks in three different human cell lines. This suggests that there is active recognition of incorporated base-analogs and nicking of DNA. The inducibility of the system of HAP repair was indicated by the shape of HAP dose response on the frequency of DNA strand breaks. We suggest and provide the evidence that one component of the repair 


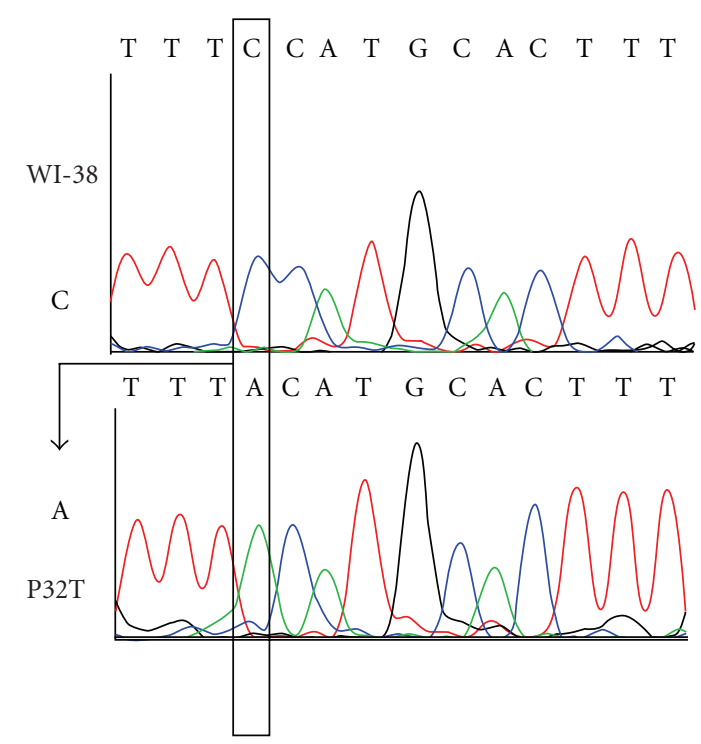

FIGURE 2: Verification of the genotype of the P32T cell line. Electropherogram of the DNA sequence of the region with C94A mutation is shown. The experiment was performed as described in Section 2.

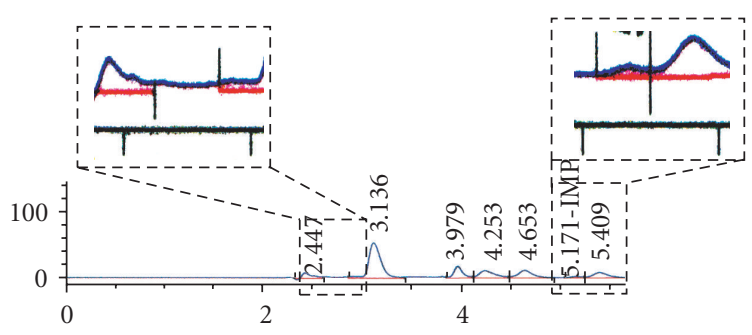

(a) HPLC analysis of WI-38 extract.

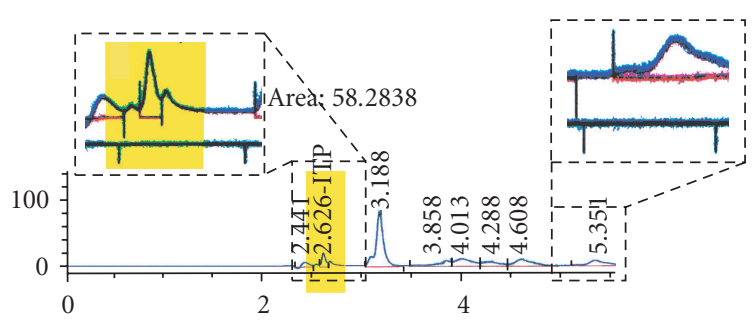

(b) HPLC analysis of P32T extract.

Figure 3: Accumulation of ITP in the P32T cell line. Areas of chromatogram corresponding to ITP and IMP are enlarged in boxes above the actual printout. Whole-cell lysates corresponding to $100 \mu \mathrm{g}$ of protein were deproteinized by acid extraction with $1 \mathrm{~N} \mathrm{HCl}$ followed by alkali treatment with an equal volume of $1 \mathrm{~N}$ $\mathrm{NaOH}$. The samples were centrifuged at 14,000 RPM for $10 \mathrm{~min}$. The volume of aqueous fraction (supernatant) was adjusted to $500 \mathrm{uL}$ with HPLC-grade water. The samples were run on an Alltech hypersil BDS C18 5u column. The HP 1100 HPLC connected to an autosampler and a DAD detector (which was set at $262 \mathrm{~nm}$ ) was used. Flow rate was kept constant at $1.1 \mathrm{~mL} / \mathrm{min}$, and a gradient flow was used: 0 to 5 minutes, $100 \%$ (a). $5-5: 10$ ramp up to $100 \%$ (b), $5: 10-8: 10,100 \%$ (b), $8: 10-8: 20$ ramp down to $100 \%$ (a). In the preliminary experiments we have determined the retention of pure $0.5 \mathrm{mM}$ solutions of ITP $(\sim 2.6)$ and IMP $(\sim 5.2)$.

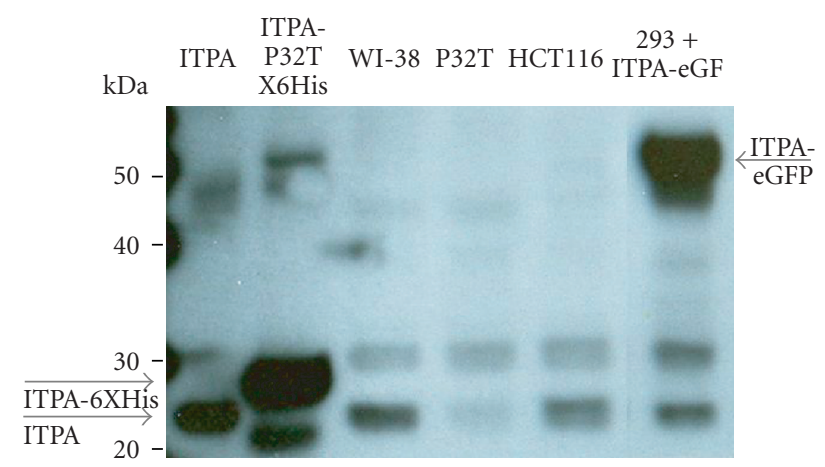

FIGURE 4: Specificity of polyclonal antibodies against ITPA in Western blot. Western blots were performed as described in Section 2. Antibodies against ITPA react largely with ITPA (a band closer to $20 \mathrm{kDa}$ marker, see compared with lane where pure ITPA was loaded, and predicted molecular mass was $21.4 \mathrm{kDa}$ ) and, less intense, with an unrelated protein running at $30 \mathrm{kDa}$. The level of ITPA, but not of this non-specific protein, is decreased almost 10fold in the soluble fraction of the P32T cell line. In the control reprobing experiment the amount of GAPDH was the same in all three cell lines (not shown). The position of the immunoreactive band was shifted up, closer to the $30 \mathrm{kDa}$ marker in the lane with the 6 His-tagged pure ITPA-P32T (predicted molecular mass $23.6 \mathrm{kDa}$ [47]). We also analyzed the extracts of 293 cell lines transfected with expressing ITPA-EGFP fusion protein $(51.4 \mathrm{kDa})$ and have found that the major band was detected at a position corresponding to $50 \mathrm{kD}$.

system is ITPA. Consistent with this, the level of spontaneous and base-analog-induced DNA damage was elevated in cell line P32T with compromised ITPA activity. The levels and distribution of ITPA P32T as determined by immunostaining have been changed in the P32T cell line. The results suggest that patients with the $94 \mathrm{C}->\mathrm{A}$ polymorphism in the ITPA 


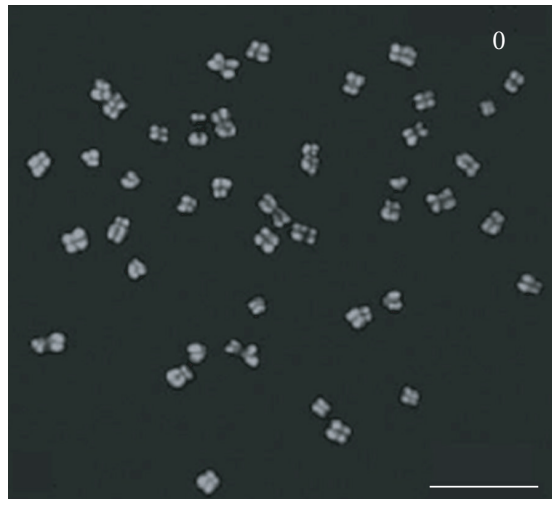

(a)

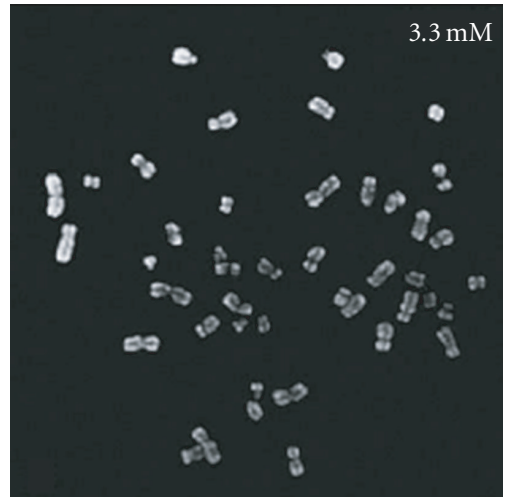

(b)

FIGURE 5: HAP does not induce massive chromosome fragmentation. The untreated HCT116 metaphase spreads (a) and HCT116 metaphase spreads obtained at the end of treatment by $3.3 \mathrm{mM} \mathrm{HAP}$ (b) were counterstained with DAPI (grey). Bar- $10 \mu \mathrm{m}$.

in addition to drug intolerance might possess increased predisposition to diseases resulting from DNA repair defects.

\section{Materials and Methods}

2.1. Human Cell Cultures. The normal, diploid, human lung fibroblast cell line, WI-38, (ATCC CCL-75) was kindly provided by Dr. Vera Gorbunova (University of Rochester, NY). The human fibroblast cell line (Coriell Institute Biorepository (GMO1617), called here $\mathrm{P} 32 \mathrm{~T}$, is homozygous for a $\mathrm{C}>\mathrm{A}$ transversion of nucleotide $94(94 \mathrm{C}>\mathrm{A})$ in exon 2 of the ITPA gene. This leads to a proline to threonine substitution at codon 32 (P32T). These untransformed cell lines were cultivated as a monolayer in MEM (Invitrogen, USA) supplemented with $10 \%$ fetal calf serum (GIBCO) and $1 \mathrm{mM}$ sodium pyruvate (Invitrogen, USA) at $37^{\circ} \mathrm{C}$ in a 5\% $\mathrm{CO}_{2}$ atmosphere. For the fibroblasts, cells at early passages ( $<25$ passages) were used in all experiments to avoid complications of replicative senescence because WI-38 cells have a mean lifespan of approximately 45 to 60 population doublings.

The epithelial colorectal cancer cell line HCT116 (ATCC, CCL247, kindly provided by Dr. Robert E. Lewis, UNMC), was cultivated in DMEM (Invitrogen, USA) containing 10\% fetal calf serum at $37^{\circ} \mathrm{C}$ in a $5 \% \mathrm{CO}_{2}$ atmosphere. The colorectal cancer HCT116 cells are defective in mismatch repair due to a nonsense mutation in the MLH1 gene [64]. For the experiment addressing the specificity of our antibodies against ITPA, we transfected colorectal carcinoma 293 cells by pEGFP plasmid (obtained from Dr. A. Rizzino, UNMC) with ITPA cloned into BamH1-EcoRI sites in frame with EGFP.

2.2. Characterization of P32T Fibroblast Cell Line. We verified the presence of the $94 \mathrm{C}->\mathrm{A}$ change in the ITPA gene by sequencing of exon 2 amplified from genomic DNA (as exon 2-4 fragment) or from RNA. For genomic DNA isolation, $1 \times 10^{6}$ cells were harvested for fibroblasts bearing wild-type (WI-38) or mutant (P32T) ITPA, and DNA was isolated according to the Fermentas Inc. protocol: (http://www.fermentas.com/en/support/application-protocols). Briefly, cell pellets were lysed with SDS and Proteinase K. After incubation with $\mathrm{NaCl}$, DNA was phenol:chloroform extracted and precipitated with ethanol. DNA pellets thus obtained were resuspended in nuclease-free water. For RNA extraction we have used the RNeasy kit (Qiagen, USA). The cDNA synthesis was performed using the qScript DNA synthesis kit (Quanta Biosciences \#95047-025).

For amplification of the specific ITPA region encompassing the site of the 94C->A change, either genomic DNA or cDNA was diluted 100-fold and exons 2 through 4 were amplified using Exons 2, 3, 4 forward and reverse primers and conditions [65]. Sequencing of the genomic fragment was performed by the same primers and the sequence of the cDNA fragment was performed using ITPA-sN 5'TCATTGGTGGGGAAGAAGATC and ITPA-sC 5'AAGCTGCCAAACTGCCAAA. The sequencing confirmed that the $\mathrm{P} 32 \mathrm{~T}$ cell line possesses $94 \mathrm{C}->\mathrm{A}$ transversions (Figure 2).

We also detected the hallmark accumulation of ITP in the P32T cell line by HPLC, confirming that ITPA activity is compromised in this cell line [65] (Figure 3).

2.3. The Alkaline Comet Assay. All the required chemicals were purchased from Trevigen, Inc. (USA). The comet assay was carried out under alkaline conditions, as described in the attached Trevigen instructions. Cells (WI-38, HCT116 and $\mathrm{P} 32 \mathrm{~T}$ ) with or without $\mathrm{H}_{2} \mathrm{O}_{2}$ or HAP treatment were suspended in $1 \%$ low melting point agarose in $1 \mathrm{xPBS}, \mathrm{pH}$ 7.4 , at $37^{\circ} \mathrm{C}$ and immediately pipetted onto a CometSlide. The agarose was allowed to set at $4^{\circ} \mathrm{C}$ for $10-30 \mathrm{~min}$ and the slide was immersed in a lysis solution at $4^{\circ} \mathrm{C}$ for $50 \mathrm{~min}$ to remove cellular proteins. Slides were then placed at $0.3 \mathrm{M}$ $\mathrm{NaOH}$ and $1 \mathrm{mM}$ EDTA for $45 \mathrm{~min}$ at room temperature before electrophoresis at $300 \mathrm{~mA}$ for $60 \mathrm{~min}$ at $4^{\circ} \mathrm{C}$. The slides were then washed two times for $10 \mathrm{~min}$ each with water and then dehydrated in $70 \%$ ethanol for $5 \mathrm{~min}$ before staining with 1xSYBR Green I staining solution. To prevent background DNA damage, handling samples and all the steps 

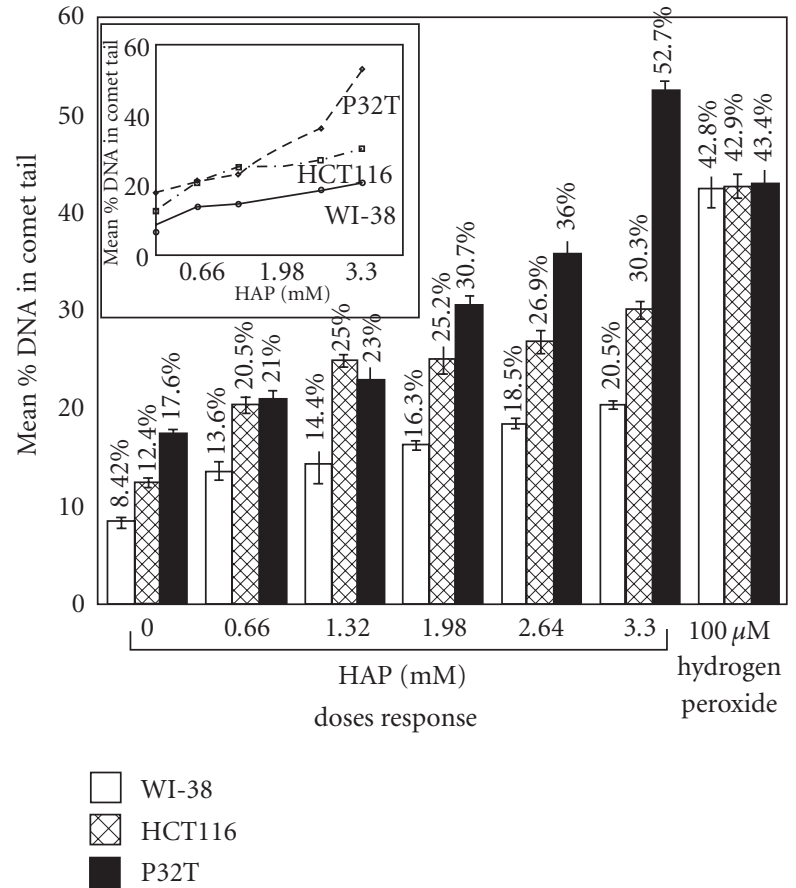

(a)

HAP doses response

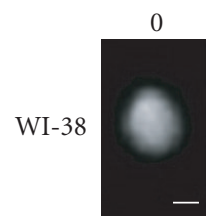

(a)

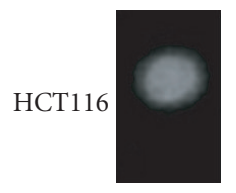

(d)

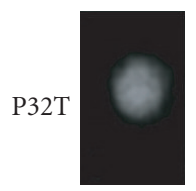

(g)

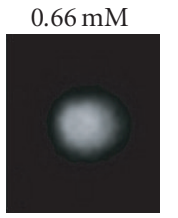

(b)

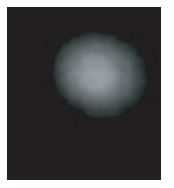

(e)

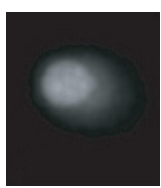

(h)

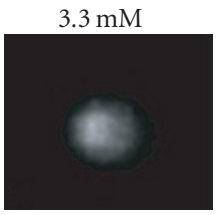

(c)

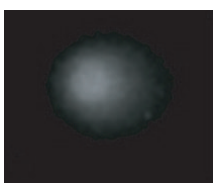

(f)

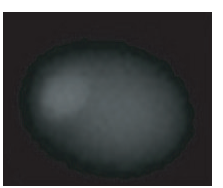

(i) (b)

FIgure 6: HAP induces DNA breaks in human cells. The effect of HAP and $100 \mu \mathrm{M}$ hydrogen peroxide on the frequency of singlestranded breaks recorded at the end of treatment in WI-38, HCT116 and P32T cell cultures by single-cell electrophoresis at $\mathrm{pH}>13$. (a) Analysis of the concentration-dependent effects of HAP and hydrogen peroxide on the frequency of DNA strand breaks in WI-38, HCT116 and P32T cells. The damaging DNA-agent dose responses are plotted on the $x$-axis. The mean percent DNA in the comet tail is plotted on the $y$-axis as a ratio of the amount of DNA in the comet tail/the amount of DNA in the whole comet. The insert in the upper part of the plot is a linear plot of this correlation for each culture. Results are shown as means \pm standard error of results of six different experiments. The level of statistical significance was set at $P<.05$. (b) Micrographs of WI-38 (a, b, c), HCT116 (d, e, $\mathrm{f}$ ), and P32T ( $\mathrm{g}, \mathrm{h}, \mathrm{i})$ cells treated with different doses of HAP: 0 (a, d, g), $0.66 \mathrm{mM}$ (b, e, h) and $3.3 \mathrm{mM}(\mathrm{c}, \mathrm{f}, \mathrm{i})$ for $24 \mathrm{hr}$. Bar- $10 \mu \mathrm{m}$.

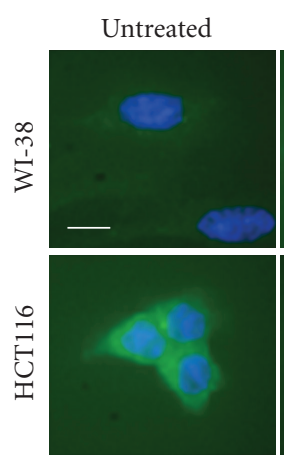

Untreated
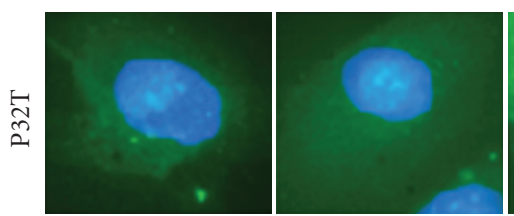

(a)
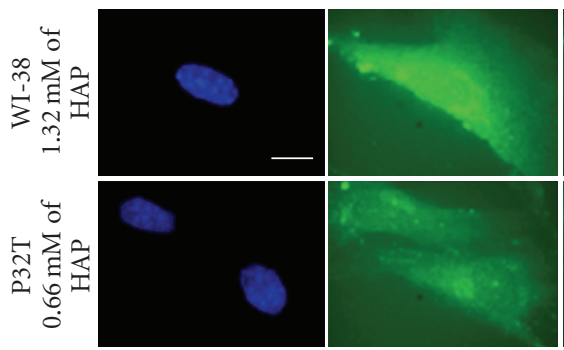

(b)

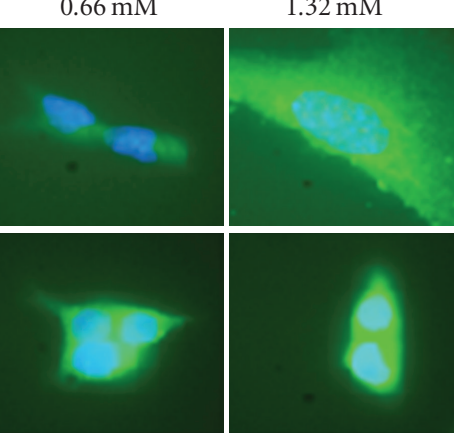

$0.66 \mathrm{mM}$
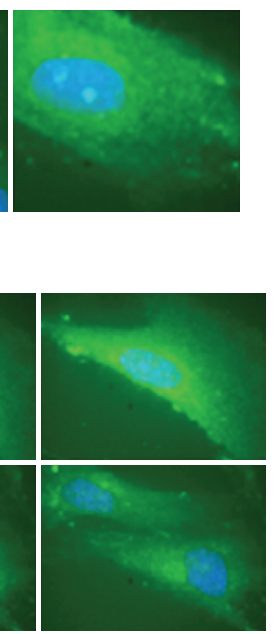

FIGURE 7: Intracellular localization and induction of ITPA. (a) The effect of HAP on ITPA levels and distribution in the WI38, HCT116 and P32T cells. Immunofluorescence of ITPA in the WI-38, upper row, HCT116, middle row and P32T, lower row. Immunostaining and counterstaining were performed with antirabbit monoclonal antibody (green) and DAPI (blue), respectively. Bar $-10 \mu \mathrm{m}$ Representative images are shown. (b) Details of immunofluorescence pattern of ITPA in the HAPtreated WI-38 (upper row, $1.32 \mathrm{mM} \mathrm{HAP}$ ) and P32T (lower row, $0.66 \mathrm{mM} \mathrm{HAP}$ ) cells. Left column-DAPI only, middle column—-detection of ITPA antibodies, and right column-merged picture.

included in the preparation of the slides for the comet assay were conducted under yellow light or in the dark.

The slides were examined using an epifluorescence microscope "Nikon Eclipse 80i." A total of 100 comets per slide were scored. Comets were randomly captured at a constant depth of the gel, avoiding the edges of the gel, occasional dead cells, and superimposed comets. The percent (\%) of DNA in the comet tail was used in this study as the measure of DNA damage. Consistent with the Trevigen Inc. application guide, the average content of DNA in the comet tail of untreated normal cells is less than ten percent. The amount of DNA in the comet tail was estimated by computerized image analysis of selected comets using CometScore software. Six independent experiments were performed. Then, the average and standard error was 


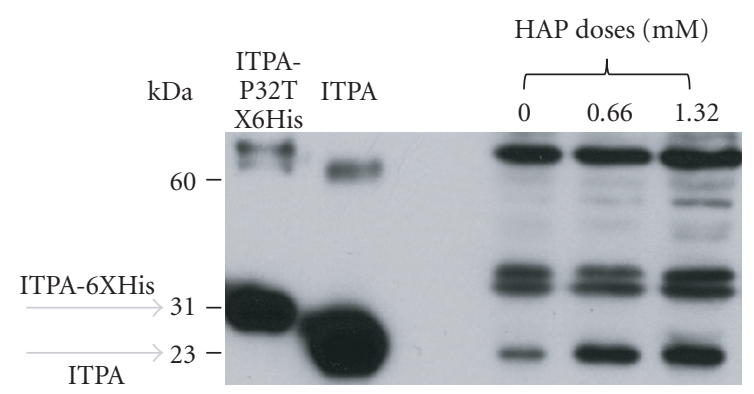

FIGURE 8: HAP treatment leads to the increase of ITPA levels in HCT116 cell extracts. Western blots were performed as described in Section 2. Two controls are in the left part: first lane-His-tagged pure ITPA $(30 \mathrm{kDA})$, second lane:-pure ITPA $(23 \mathrm{kDa})$. Third, fourth, and fifth lane shows the levels of ITPA $(23 \mathrm{kDA})$ in extract of untreated cells, and cells treated by $0.66 \mathrm{mM}$ HAP and $1.32 \mathrm{mM}$ HAP. To estimate the induction of ITPA, we measured the ratio of the intensity of the band corresponding to monomeric ITPA to nonspecific bands. Estimated by this method, the induction relative to the control was 2.2 times at $0.66 \mathrm{mM}$ and 2.6 times at $1.32 \mathrm{mM}$.

determined. The statistical significance of differences was estimated by Student's $t$-criterion.

2.4. Chromosome Analysis. For metaphase chromosome spreads, WI-38, HCT116, and P32T cells (treated for $23 \mathrm{~h}$ with DMSO or HAP in DMSO) were arrested in metaphase by a $1 \mathrm{~h}$ treatment with $0.5 \mu \mathrm{g} / \mathrm{ml}$ colcemide (Gibco URL, USA), treated hypotonically with $0.075 \mathrm{M} \mathrm{KCl}$, fixed three times in a 3:1 methanol-acetic acid mixture, spread on glass slides, and air dried. Twenty spreads for each culture were analyzed by CytoVision software (Genetix Corp., CA); only the total number and size of the chromosomes were determined.

2.5. Western Blot Analysis. HCT116, WI-38, and P32T cells were cultivated until subconfluence $\left(5 \times 10^{5}\right.$ cells per plate). The cells were harvested and resuspended in the lysis buffer (1xPBS containing a protease inhibitor cocktail (Roche Biochemicals, IN, USA), $\mathrm{pH}=7.4$ ). Each pellet was mechanically sheared using a pestle. The lysate was cleared by centrifugation and protein content determined by Bradford reagent from BioRad. The lysate equivalent to $100 \mu \mathrm{g}$ of protein was boiled in Laemli's buffer (Invitrogen, USA). The protein samples were resolved on a $10 \%-20 \%$ Tris-Glycine gel (Invitrogen, USA) by SDS-PAGE and transferred to nitrocellulose membranes. Membranes were blocked overnight in commercially available blocking buffer (Thermo Scientific, USA). Membranes were then incubated in 1:500 dilutions of primary antibody against ITPA (the in-house polyclonal antibodies against ITPA are described elsewhere [55]) and GAPDH (Cell Signaling \#2118) for one hour at room temperature. The membranes were then washed with commercially available washing buffer (Thermoscientific, USA) five times for $10 \mathrm{~min}$ each. This was followed by incubation with secondary antibody (1:1500 dilution) (Cell signaling \#7074) for $40 \mathrm{~min}$ at room temperature. This was followed by washing ( 5 times for 10 min each) and detection by the ECL system (ThermoScientific, USA) according to the manufacturer's instructions. The results are presented in Figure 4. A major visible band, corresponding to ITPA (compare with lane with pure ITPA), is prominent in WI38 fibroblasts, and cancer HCT116 cell extracts (gray arrow) but is less pronounced in P32T cells, as we described before [55]. The intensity of the non-specific $30 \mathrm{kDa}$ band is similar in all three cell lines. The position of the immunoreactive band was shifted up, closer to the $30 \mathrm{kDa}$ marker, in lane with 6 His-tagged pure ITPA-P32T (predicted molecular mass $23.6 \mathrm{kDa}$ [47]). We also analyzed the extract of 293 cell lines transfected with a plasmid expressing the gene for ITPAEGFP fusion protein $(51.4 \mathrm{kDa})$ and have found that a major band was detected at a position corresponding to $50 \mathrm{kDA}$. The data unequivocally prove that antibodies react primarily with ITPA.

For the analysis of ITPA induction by HAP by Western blots we cultivated HCT116 cells with or without HAP until subconfluence $\left(5 \times 10^{5}\right.$ cells per plate). The cells were harvested and resuspended in the lysis buffer $(50 \mathrm{mM}$ Tris, $\mathrm{pH}=8.0,1 \mathrm{mM}$ PMSF, $10 \%(\mathrm{v} / \mathrm{v})$ glycerol, $0.5 \%$ Triton X100 ) and disrupted and processed as before with the following modifications to improve the quality and resolution. The lysate equivalent to $30 \mu \mathrm{g}$ of protein was boiled in Laemli's buffer containing $100 \mathrm{mM}$ DTT and loaded on a 10\%-20\% Tris-Glycine gel by SDS-PAGE. After trial run and Coomassie staining the amount of extracts was further adjusted to produce equal amount of loaded protein in the control and treatment and run in the new gel. After transfer, nitrocellulose membranes were blocked overnight in 5\% dry milk/1x PBST. Membranes were incubated in 1:2000 dilutions of primary antibody against ITPA described above for one hour at room temperature. The membranes were washed with 1x PBST three times for $15 \mathrm{~min}$ each, and, incubated with secondary HRP-linked antibody (1:100000 dilution) (Cell Signaling \#7074) for 1 hour at room temperature. Membrane was washed three times for $15 \mathrm{~min}$ each and signals were detected by SuperSignal West Femto Maximum Sensitivity Substrate (ThermoScientific, USA) according to the manufacturer's instructions.

2.6. Immunocytochemistry. Cells (WI-38, HCT116 and P32T) with or without HAP treatment were fixed with methanol acetic acid mixture $(3: 1)$. All procedures were performed at room temperature. To prevent non-specific binding in the consequent antibody detection, samples were blocked in 1xPBS containing 5\% BSA and $0.05 \%$ Tritone $\mathrm{X}-100$. We have used the primary antibodies against ITPA described in the previous section and a goat-antirabbit antibody Alexa Fluor $488 \mathrm{~nm}$ conjugated (Thermoscientific, USA). Both antibodies were diluted $1: 1000$ in $1 \mathrm{xPBS}$ containing 5\% BSA and $0.05 \%$ Triton X-100. Slides were washed three times in 1 XPBST buffer between incubations with primary and secondary antibodies and after incubations. After washing, the cells were counterstained with DAPI, mounted in antifade medium and analyzed by fluorescent microscopy. No fluorescence was detected when primary antibodies were omitted from the protocol, and very low signal was detected when preimmune rabbit serum was used 
in place of primary antibody, suggesting that fluorescence signals were absolutely dependent on antiITPA antibodies. Three independent repeats of this experiment have been done.

2.7. Microscopy and Image Analysis. After the comet assay or immunocytochemistry procedures, cells were examined on a Nikon Eclipse 80i microscope. Images were recorded separately by a CCD device Photometrics CoolSnap cf and merged using Adobe Photoshop software.

\section{Results}

3.1. HAP Does not Cause Chromosome Hyperfragmentation in Three Human Cell Lines. It has been reported previously that treatment of human epidermoid carcinoma cells with 1 mM HAP lead to massive chromosome fragmentation (Figure 2 in [66]). We examined HAP effects on chromosomes in WI-38, HCT116, and P32T lines. We studied chromosome spreads of untreated WI-38, HCT116, and P32T cells versus the same cells treated with $3.3 \mathrm{mM}$ HAP. There were no more chromosomal abnormalities after treatment with 3.3 mM HAP than in the untreated HCT116 chromosome spreads (Figure 5). We did not observe any striking differences in the rates of chromosomal abnormalities in WI-38 and P32T chromosome spreads as well (data not shown). It is possible that the cell line used in earlier studies was hypersensitive to HAP.

3.2. The Increase in HAP Dose Proportionally Elevated the Rate of DNA Breaks in WI-38, HCT116, and P32T Cells. We investigated the effect of $24 \mathrm{~h}$ treatment by different HAP concentrations on the frequency of single-stranded breaks in WI-38, HCT116 and P32T cell cultures by single cell electrophoresis at $\mathrm{pH}>13$. Under our experimental conditions and with doses of mutagens used, no substantial cell killing occurred. The percent of DNA in the comet tail (thereafter named tail DNA) of the total DNA was used in the study as the estimate of the amount of single-stranded breaks. The mean tail DNA was statistically significantly different in the three lines: $8.42 \%$ in untreated normal WI-38 fibroblasts, $12.4 \%$ in colorectal cancer cell culture HCT116, and the highest $17.6 \%$, in $\mathrm{P} 32 \mathrm{~T}$ fibroblast cell culture, a large change for this type of assay two-fold increase over normal fibroblasts (Figure 6(a)). The increased level of tail DNA in untreated cells likely indicates persistent unrepaired endogenous damage in HCT116 and P32T cells.

WI-38 normal fibroblasts were quite resistant to HAP: the highest concentration of $3.3 \mathrm{mM}$ HAP increased tail DNA two-fold to $20.5 \%$, much less than the positive control hydrogen peroxide (42.8\% tail DNA) (Figure 6(a)). The induction curve had quite a gentle slope with a small hump/plateau of resistance when the dose increased from 0.66 to 1.32 (seen clearly in the insert in Figure 6(a)). The comet tails in WI-38 cells after treatment with $0.66 \mathrm{mM}-3.3 \mathrm{mM}$ of HAP were the shortest among the variables studied (Figure 6(b)). The response of the HCT116 cells to the hydrogen peroxide treatment was similar to that of the WI-38 cells (tail DNA was $42.9 \%$ ). HAP produced more DNA damage than in WI-38 cells. An initial eight percent increase at $0.66 \mathrm{mM}$ was followed by the plateau of around $25 \%$ tail DNA at doses $1.32 \mathrm{mM}-2.64 \mathrm{mM}$ (Figure 6(a), insert). This apparent resistance to the induction of breaks was finally concurred by $3.3 \mathrm{mM}$ of HAP and tail DNA reached $30.3 \%$ (Figure 6(a)). P32T cells were most sensitive to HAP, while the sensitivity to hydrogen peroxide was similar to other cell lines (43.4\%). The lowest dose of HAP induced as much tail DNA in P32T as the highest dose in normal fibroblasts $(21 \%)$. The 1.98 mM HAP produced $30.7 \%$ tail DNA in P32T, exceeding the maximum of tail DNA induced by HAP in other cell cultures studied at the same dose. After 3.3 mM HAP treatment of these cells, the level of tail DNA reached 52.7\% and the tail was much longer than in WI-38 and HCT116 under the same conditions (Figures 6(a) and 6(b)). In summary, HAP induced DNA breaks in human cells. HAP was moderately active in normal WI-38 fibroblasts, HCT116 cancer cells were more sensitive than WI-38 cells and P32T ITPA-deficient fibroblasts were the most susceptible.

3.3. ITPA Cellular Levels and Distribution Change Differently after HAP Treatment of WI-38, HCT116 and P32T Lines. The presence of the plateau in the dose-response curves for HAP indicated that wild-type cells might possess an inducible protection system, which is activated at $0.66-1.32 \mathrm{mM} \mathrm{HAP}$. One possible candidate is ITPA and we studied ITPA distribution after HAP treatment in WI-38, HCT116 and P32T cells by whole-cell immunostaining with specific antibodies against ITPA (specificity of antibodies has been verified by Western Blot, because of the shift of detected GFP-tagged ITPA to higher position, Figure 4).

ITPA was not readily detected in untreated WI-38 fibroblasts, and cells were stained very weakly (Figure $7(a)$ ). The detected ITPA amount increased after the treatment with $0.66 \mathrm{mM}$ and $1.32 \mathrm{mM} \mathrm{HAP}$. The untreated HCT116 cancer cells were stained with antibody against ITPA somewhat more efficiently than WI-38 cells (Figure 7(a)). The ITPA amount increased after $0.66 \mathrm{mM}$ and $1.32 \mathrm{mM}$ HAP treatment, the latter dose producing strikingly bright cytoplasm (Figure 7(a)). Maybe this phenomenon simply relates to the smaller size of cytoplasm relative to nucleus. Some ITPA was detected in untreated ITPA-deficient P32T fibroblasts, similar to HCT116 cells (Figure 7(a), lower row). After treatment with $0.66 \mathrm{mM}$ HAP, the ITPA amount increased, so induction occurred at lower dose.

Fluorescence in all cases was mostly in cytoplasm and was generally uneven. The brighter fluorescent regions in WI-38 cells were of three types. One type resembled a net structure adjacent to nuclei. Another type was small granules localized in nuclei (Figure 7(b), upper row). The third was one big bright granule, typically at the border of nuclei and cytoplasm or localized in the nuclei close to its edge. In HCT116, the heterogeneity was less pronounced and the net structure was not observed (compare to Figure $7(a)$ ). It is possible that it is undetectable due to a small cytoplasmic part of the cell and very bright fluorescence. In P32T fibroblasts the distribution was different. Net-like structure has not been observed. Some brighter regions adjacent to 
nuclei were present but they were unstructured (Figure 7(b), lower row).

We also have used Western blot analysis in HCT116 cells to confirm and quantify induction of ITPA by HAP (Figure 8). Clearly, HAP treatment leads to up to 2.6-fold elevation of the amount of ITPA.

\section{Discussion}

4.1. Response of Human Cells to Base-analog HAP Treatment. It is known that HAP is mutagenic, clastogenic and carcinogenic in hamster cells $[67,68]$. Using Comet assay we have shown that HAP produced DNA breaks in the human cell lines tested. The most logical explanation of this and other currently available data is that the baseanalog was incorporated into DNA and either human Endo $\mathrm{V}$ homolog (encoded by the LOC284131, see description of closely related mouse homolog in [51]) or other an unknown glycosylase/endonuclease recognized incorporated HAP and incised DNA strands (Figure 1).

Analysis of the dose-response curves revealed a hump/plateau region indicative of the induction of a cellular protective response/repair system. The HAPtreated WI-38 fibroblasts with wild-type ITPA had the lowest rates of DNA breaks, and untreated WI-38 cells had the lowest levels of spontaneous breaks among cell lines studied. The hump in the dose-response curve indicated that there is an induction of the repair activity at 0.66-1.32 mM HAP.

We found moderately elevated levels of spontaneous breaks in HCT116. It remains to be determined whether this effect is related to the defect of a mismatch-repair system. The levels of DNA breaks by HAP in HCT116 cells were higher than in WI-38 fibroblasts and the analysis of the doseresponse curve indicated that the repair system most likely was activated completely only by $1.32 \mathrm{mM}$ HAP.

The P32T ITPA-deficient fibroblasts were the most sensitive to the induction of DNA breaks by HAP treatment. We propose that deoxyribonucleoside triphosphates of HAP, usually removed by ITPA in wild-type cell lines, remain in the detectable amount in the DNA precursor pools of ITPA P32T fibroblasts. They are incorporated in DNA causing the excess of DNA breaks. This observation correlates well with the accumulation of ITP only in this cell line (Figure 3 ). It is known that ITPA P32T produced ectopically protects bacteria and yeast from HAP to the same extent as wildtype ITPA, but the level of ITPA P32T in human cell extracts is much lower than in normal fibroblasts [62]. Apparently, the human repair system does not work properly in P32T cells alleviating DNA damage by downstream repair enzymes. The spontaneous level of DNA breaks in this cell line was the highest, raising the possibility that there is persistent endogenous DNA damage in these cells. It is tempting to speculate that the damage is caused by endogeous dITP/dXTP.

The next set of experiments explored one possible component of the HAPinduced repair system.

4.2. ITPA Levels and Distribution in HAP Treated Human Cells. We have analyzed in detail the levels and intracellular distribution of ITPA. We confirmed that the enzyme is located mainly in cytoplasm [69]. We have found that ITPA levels increased significantly upon treatment with HAP in all the investigated cells, although it was significantly lower in the ITPA P32T fibroblasts than in WI-38 and HCT116 cells. P32T ITPA-deficient fibroblasts responded by the production of ITPA to much lower doses of HAP, because the destruction of HAPTP is less efficient in these cells and effective concentrations of substrates for the ITPA are higher.

The antibody staining revealed a net-like structure adjacent to nuclei and other, granular structures in the WI-38 normal fibroblasts, when ITPA is induced by HAP. This is consistent with previous analyses of the localization of ITPA to purine biosynthetic complexes. It has been shown previously that human enzymes involved in de novo purine biosynthesis (for example, hTrifGART protein, and formylglycinamidine ribonucleotide synthase, PRPP amidotransferase, hPAICS, adenylosuccinate lyase and hATIC), colocalize and cluster in human cell cytoplasm [70]. This is consistent with the hypothesis that these clusters represent a "purinosome"-an organoid essential for purine biosynthesis. Usually these clusters localized throughout the whole cytoplasm volume but there were one or two big clusters on the border of nuclei and cytoplasm. One possible interpretation of our results is that ITPA, the enzyme of purine "salvage" pathway, constitutes a part of this purinosome. The candidate structure is a big fluorescent granule. Further colocalization experiments are needed to test our hypothesis.

Hypothetically, the net-like structure described here may represent a factory checking quality of dNTP pools. It is possible that this abnormal ITPA distribution is one of the reasons for a lack of ITPA function in P32T individuals, despite almost normal activity of the enzyme [62].

Taken together, our results suggest that human cells possess a repair system for purine base-analogs similar, in part, to bacteria. The genetically active derivative of HAP is deoxyribonucleoside triphosphate. Cells are protected from dHAPTP by hydrolysis by ITPA. Some dHAPTP is presumably incorporated into DNA, and subsequent repair of HAP leads to DNA strand breaks.

\section{Acknowledgments}

The authors are grateful to Dr. S. Kozmin, Dr. I. M. Spivak, and Dr. N. E. Enukashvili for critical reading of the manuscript and helpful comments. They thank Coriell Repository for the P32T cell line. The work was supported by an NE DHHS LB506 Grant, by a UNMC Eppley Cancer Center 010107 Pilot Grant, and in part, by NCI Grant R01 CA129925 to Youri I. Pavlov. Miriam R. Menezes was supported by a UNMC graduate student fellowship. I. S.-R. Waisertreiger and M. R. Menezes contributed equally to this work.

\section{References}

[1] E. C. Friedberg, DNA Repair and Mutagenesis, ASM Press, Washington, DC, USA, 2006. 
[2] B. N. Ames and L. S. Gold, "Endogenous mutagens and the causes of aging and cancer," Mutation Research, vol. 250, no. 1-2, pp. 3-16, 1991.

[3] H. Kamiya, "Mutagenic potentials of damaged nucleic acids produced by reactive oxygen/nitrogen species: approaches using synthetic oligonucleotides and nucleotides," Nucleic Acids Research, vol. 31, no. 2, pp. 517-531, 2003.

[4] P. C. Dedon and S. R. Tannenbaum, "Reactive nitrogen species in the chemical biology of inflammation," Archives of Biochemistry and Biophysics, vol. 423, no. 1, pp. 12-22, 2004.

[5] M. Hori, C. Ishiguro, H. Harashima, and H. Kamiya, "In vivo mutagenicities of damaged nucleotides produced by nitric oxide and ionizing radiation," Biological and Pharmaceutical Bulletin, vol. 28, no. 3, pp. 520-522, 2005.

[6] S. Haghdoost, L. Sjölander, S. Czene, and M. Harms-Ringdahl, "The nucleotide pool is a significant target for oxidative stress," Free Radical Biology and Medicine, vol. 41, no. 4, pp. 620-626, 2006.

[7] H. Ohshima, T. Sawa, and T. Akaike, "8-Nitroguanine, a product of nitrative DNA damage caused by reactive nitrogen species: formation, occurrence, and implications in inflammation and carcinogenesis," Antioxidants and Redox Signaling, vol. 8, no. 5-6, pp. 1033-1045, 2006.

[8] C. K. Mathews, "DNA precursor metabolism and genomic stability," FASEB Journal, vol. 20, no. 9, pp. 1300-1314, 2006.

[9] R. G. Fowler and R. M. Schaaper, "The role of the mutT gene of Escherichia coli cell in maintaining replication fidelity," FEMS Microbiology Reviews, vol. 21, no. 1, pp. 43-54, 1997.

[10] E. A. Kouzminova and A. Kuzminov, "Chromosomal fragmentation in dUTPase-deficient mutants of Escherichia coli and its recombinational repair," Molecular Microbiology, vol. 51, no. 5, pp. 1279-1295, 2004.

[11] E. A. Kouzminova and A. Kuzminov, "Fragmentation of replicating chromosomes triggered by uracil in DNA," Journal of Molecular Biology, vol. 355, no. 1, pp. 20-33, 2006.

[12] E. A. Kouzminova and A. Kuzminov, "Patterns of chromosomal fragmentation due to uracil-DNA incorporation reveal a novel mechanism of replication-dependent double-stranded breaks," Molecular Microbiology, vol. 68, no. 1, pp. 202-215, 2008.

[13] A. L. Jackson and L. A. Loeb, "The mutation rate and cancer," Genetics, vol. 148, no. 4, pp. 1483-1490, 1998.

[14] P. Rai, T. T. Onder, J. J. Young et al., "Continuous elimination of oxidized nucleotides is necessary to prevent rapid onset of cellular senescence," Proceedings of the National Academy of Sciences of the United States of America, vol. 106, no. 1, pp. 169174, 2009.

[15] T. Nunoshiba, T. Watanabe, Y. Nakabeppu, and K. Yamamoto, "Mutagenic target for hydroxyl radicals generated in Escherichia coli mutant deficient in $\mathrm{Mn}$ - and Fe-superoxide dismutases and Fur, a repressor for iron-uptake systems," DNA Repair, vol. 1, no. 5, pp. 411-418, 2002.

[16] K. C. Cheng, D. S. Cahill, H. Kasai, S. Nishimura, and L. A. Loeb, "8-Hydroxyguanine, an abundant form of oxidative DNA damage, causes $\mathrm{G} \rightarrow \mathrm{T}$ and $\mathrm{A} \rightarrow \mathrm{C}$ substitutions," The Journal of Biological Chemistry, vol. 267, no. 1, pp. 166-172, 1992.

[17] H. Maki and M. Sekiguchi, "MutT protein specifically hydrolyses a potent mutagenic substrate for DNA synthesis," Nature, vol. 355, no. 6357, pp. 273-275, 1992.

[18] Y. I. Pavlov, D. T. Minnick, S. Izuta, and T. A. Kunkel, "DNA replication fidelity with 8-oxodeoxyguanosine triphosphate," Biochemistry, vol. 33, no. 15, pp. 4695-4701, 1994.
[19] M. L. Michaels and J. H. Miller, "The GO system protects organisms from the mutagenic effect of the spontaneous lesion 8-hydroxyguanine (7,8-dihydro-8-oxoguanine)," Journal of Bacteriology, vol. 174, no. 20, pp. 6321-6325, 1992.

[20] E. C. Cox, "Mutator gene studies in Escherichia coli: the mutT gene," Genetics, vol. 73, no. 1973, pp. 67-80, 1973.

[21] E. Rotman and A. Kuzminov, "The mutT defect does not elevate chromosomal fragmentation in Escherichia coli because of the surprisingly low levels of MutM/MutY-recognized DNA modifications," Journal of Bacteriology, vol. 189, no. 19, pp. 6976-6988, 2007.

[22] B. Pang, X. Zhou, H. Yu et al., "Lipid peroxidation dominates the chemistry of DNA adduct formation in a mouse model of inflammation," Carcinogenesis, vol. 28, no. 8, pp. 1807-1813, 2007.

[23] T. Simandan, J. Sun, and T. A. Dix, "Oxidation of DNA bases, deoxyribonucleosides and homopolymers by peroxyl radicals," Biochemical Journal, vol. 335, no. 2, pp. 233-240, 1998.

[24] B. Clement and T. Kunze, "Hepatic microsomal N-hydroxylation of adenine to 6-N-hydroxylaminopurine," Biochemical Pharmacology, vol. 39, no. 5, pp. 925-933, 1990.

[25] I. Lieberman, "Enzymatic synthesis of adenosine-5'phosphate from inosine- $5^{\prime}$-phosphate," The Journal of Biological Chemistry, vol. 223, no. 1, pp. 327-339, 1956.

[26] S. G. Kozmin, R. M. Schaaper, P. V. Shcherbakova et al., "Multiple antimutagenesis mechanisms affect mutagenic activity and specificity of the base analog 6-N-hydroxylaminopurine in bacteria and yeast," Mutation Research, vol. 402, no. 1-2, pp. 41-50, 1998.

[27] N. E. Burgis, J. J. Brucker, and R. P. Cunningham, "Repair system for noncanonical purines in Escherichia coli," Journal of Bacteriology, vol. 185, no. 10, pp. 3101-3110, 2003.

[28] M. T. Abdul-Masih and M. J. Bessman, "Biochemical studies on the mutagen, 6-N-hydroxylaminopurine. Synthesis of the deoxynucleoside triphosphate and its incorporation into DNA in vitro," The Journal of Biological Chemistry, vol. 261, no. 5, pp. 2020-2026, 1986.

[29] Y. I. Pavlov, V. V. Suslov, P. V. Shcherbakova et al., "Base analog N6-hydroxylaminopurine mutagenesis in Escherichia coli: genetic control and molecular specificity," Mutation Research, vol. 357, no. 1-2, pp. 1-15, 1996.

[30] N. E. Burgis and R. P. Cunningham, "Substrate specificity of RdgB protein, a deoxyribonucleoside triphosphate pyrophosphohydrolase," The Journal of Biological Chemistry, vol. 282, no. 6, pp. 3531-3538, 2007.

[31] S. Quirk, S. K. Bhathnagar, and M. J. Bessman, "Primary structure of the deoxyguanosine triphosphate triphosphohydrolase-encoding gene (dgt) of Escherichia coli," Gene, vol. 89, no. 1, pp. 13-18, 1990.

[32] D. Gawel, M. D. Hamilton, and R. M. Schaaper, "A novel mutator of Escherichia coli carrying a defect in the dgt gene, encoding a dGTP triphosphohydrolase," Journal of Bacteriology, vol. 190, no. 21, pp. 6931-6939, 2008.

[33] J. Zheng, V. K. Singh, and Z. Jia, "Identification of an ITPase/XTPase in Escherichia coli by structural and biochemical analysis," Structure, vol. 13, no. 10, pp. 1511-1520, 2005.

[34] B. Budke and A. Kuzminov, "Production of clastogenic DNA precursors by the nucleotide metabolism in Escherichia coli," Molecular Microbiology, vol. 75, no. 1, pp. 230-245, 2010.

[35] T. Iyama, N. Abolhassani, D. Tsuchimoto, M. Nonaka, and Y. Nakabeppu, "NUDT16 is a (deoxy)inosine diphosphatase, and its deficiency induces accumulation of single-strand breaks in 
nuclear DNA and growth arrest," Nucleic Acids Research, vol. 2010, p. 12, 2010.

[36] T. Kohno, H. Kunitoh, K. Toyama et al., "Association of the OGG1-Ser326Cys polymorphism with lung adenocarcinoma risk," Cancer Science, vol. 97, no. 8, pp. 724-728, 2006.

[37] A. M. Marinaki, J. A. Duley, M. Arenas et al., "Mutation in the ITPA gene predicts intolerance to azathioprine," Nucleosides, Nucleotides and Nucleic Acids, vol. 23, no. 8-9, pp. 1393-1397, 2004.

[38] J. Fellay, A. J. Thompson, D. Ge et al., "ITPA gene variants protect against anaemia in patients treated for chronic hepatitis C," Nature, vol. 464, no. 7287, pp. 405-408, 2010.

[39] J. S. Bradshaw and A. Kuzminov, "RdgB acts to avoid chromosome fragmentation in Escherichia coli," Molecular Microbiology, vol. 48, no. 6, pp. 1711-1725, 2003.

[40] S. Lin, A. G. McLennan, K. Ying et al., "Cloning, expression, and characterization of a human inosine triphosphate pyrophosphatase encoded by the itpa gene," The Journal of Biological Chemistry, vol. 276, no. 22, pp. 18695-18701, 2001.

[41] S. Takayama, M. Fujii, A. Kurosawa, N. Adachi, and D. Ayusawa, "Overexpression of HAM1 gene detoxifies 5bromodeoxyuridine in the yeast Saccharomyces cerevisiae," Current Genetics, vol. 52, no. 5-6, pp. 203-211, 2007.

[42] K. Y. Hwang, J. H. Chung, S.-H. Kim, Y. Sun Han, and Y. Cho, "Structure-based identification of a novel NTPase from Methanococcus jannaschii," Nature Structural Biology, vol. 6, no. 7, pp. 691-696, 1999.

[43] S. G. Kozmin, Y. I. Pavlov, R. L. Dunn, and R. M. Schaaper, "Hypersensitivity of Escherichia coli D(uvrB-bio) mutants to 6hydroxylaminopurine and other base analogs is due to a defect in molybdenum cofactor biosynthesis," Journal of Bacteriology, vol. 182, no. 12, pp. 3361-3367, 2000.

[44] S. G. Kozmin and R. M. Schaaper, "Molybdenum cofactordependent resistance to $\mathrm{N}$-hydroxylated base analogs in Escherichia coli is independent of MobA function," Mutation Research, vol. 619, no. 1-2, pp. 9-15, 2007.

[45] S. G. Kozmin, P. Leroy, Y. I. Pavlov, and R. M. Schaaper, "YcbX and yiiM, two novel determinants for resistance of Escherichia coli to N-hydroxylated base analogues," Molecular Microbiology, vol. 68, no. 1, pp. 51-65, 2008.

[46] L. Lukas and A. Kuzminov, "Chromosomal fragmentation is the major consequence of the $r d g B$ defect in Escherichia coli," Genetics, vol. 172, no. 2, pp. 1359-1362, 2006.

[47] J. Porta, C. Kolar, S. G. Kozmin, Y. I. Pavlov, and G. E. O. Borgstahl, "Structure of the orthorhombic form of human inosine triphosphate pyrophosphatase," Acta Crystallographica Section F, vol. 62, no. 11, pp. 1076-1081, 2006.

[48] I. I. Pavlov, "Mutants of Saccharomyces cerevisiae supersensitive to the mutagenic effect of 6-N-hydroxylaminopurine," Genetika, vol. 22, no. 9, pp. 2235-2243, 1986.

[49] V. N. Noskov, K. Staak, P. V. Shcherbakova et al., "HAM1, the gene controlling 6-N-hydroxylaminopurine sensitivity and mutagenesis in the yeast Saccharomyces cerevisiae," Yeast, vol. 12, no. 1, pp. 17-29, 1996.

[50] B. Budke and A. Kuzminov, "Hypoxanthine incorporation is nonmutagenic in Escherichia coli," Journal of Bacteriology, vol. 188, no. 18, pp. 6553-6560, 2006.

[51] A. Moe, J. Ringvoll, L. M. Nordstrand et al., "Incision at hypoxanthine residues in DNA by a mammalian homologue of the Escherichia coli antimutator enzyme endonuclease V," Nucleic Acids Research, vol. 31, no. 14, pp. 3893-3900, 2003.

[52] M. Y. Galperin, O. V. Moroz, K. S. Wilson, and A. G. Murzin, "House cleaning, a part of good housekeeping," Molecular Microbiology, vol. 59, no. 1, pp. 5-19, 2006.
[53] M. Behmanesh, K. Sakumi, N. Abolhassani et al., "ITPasedeficient mice show growth retardation and die before weaning," Cell Death and Differentiation, vol. 16, no. 10, pp. 13151322, 2009.

[54] J. A. Duley, A. M. Marinaki, M. Arenas, and T. H. J. Florin, "Do ITPA and TPMT genotypes predict the development of side effects to AZA?" Gut, vol. 55, no. 7, pp. 1048-1049, 2006.

[55] J. M. van Dieren, A. J. van Vuuren, J. G. Kusters, E. E. S. Nieuwenhuis, E. J. Kuipers, and C. J. Van Der Woude, "ITPA genotyping is not predictive for the development of side effects in AZA treated inflammatory bowel disease patients," Gut, vol. 54, no. 11, p. 1664, 2005.

[56] A. M. Marinaki, A. Ansari, J. A. Duley et al., "Adverse drug reactions to azathioptine therapy are associated with polymorphism in the gene encoding inosine triphosphate pyrophosphatase (ITPase)," Pharmacogenetics, vol. 14, no. 3, pp. 181-187, 2004.

[57] T. Maeda, S. Sumi, A. Ueta et al., "Genetic basis of inosine triphosphate pyrophosphohydrolase deficiency in the Japanese population," Molecular Genetics and Metabolism, vol. 85, no. 4, pp. 271-279, 2005.

[58] M. Shipkova, K. Lorenz, M. Oellerich, E. Wieland, and N. Von Ansen, "Measurement of erythrocyte inosine triphosphate pyrophosphohydrolase (ITPA) activity by HPLC and correlation of ITPA genotype-phenotype in a Caucasian population,” Clinical Chemistry, vol. 52, no. 2, pp. 240-247, 2006.

[59] N. von Ahsen, V. W. Armstrong, C. Behrens et al., "Association of inosine triphosphatase $94 \mathrm{C}>\mathrm{A}$ and thiopurine Smethyltransferase deficiency with adverse events and study drop-outs under azathioprine therapy in a prospective Crohn disease study," Clinical Chemistry, vol. 51, no. 12, pp. 22822288, 2005.

[60] G. Stocco, M. H. Cheok, K. R. Crews et al., "Genetic polymorphism of inosine triphosphate pyrophosphatase is a determinant of mercaptopurine metabolism and toxicity during treatment for acute lymphoblastic leukemia," Clinical Pharmacology and Therapeutics, vol. 85, no. 2, pp. 164-172, 2009.

[61] N. Abolhassani, T. Iyama, D. Tsuchimoto et al., "NUDT16 and ITPA play a dual protective role in maintaining chromosome stability and cell growth by eliminating dIDP/IDP and dITP/ITP from nucleotide pools in mammals," Nucleic Acids Research, vol. 38, no. 9, pp. 2891-2903, 2010.

[62] E. I. Stepchenkova, E. R. Tarakhovskaya, K. Spitler et al., "Functional study of the P32T ITPA variant associated with drug sensitivity in humans," Journal of Molecular Biology, vol. 392, no. 3, pp. 602-613, 2009.

[63] G. Herting, K. Barber, M. R. Zappala, R. P. Cunningham, and N. E. Burgis, "Quantitative in vitro and in vivo characterization of the human P32T mutant ITPase," Biochimica et Biophysica Acta, vol. 1802, pp. 269-274, 2009.

[64] S. Jacob, M. Aguado, D. Fallik, and F. Praz, "The role of the DNA mismatch repair system in the cytotoxicity of the topoisomerase inhibitors camptothecin and etoposide to human colorectal cancer cells," Cancer Research, vol. 61, no. 17, pp. 6555-6562, 2001.

[65] S. Sumi, A. M. Marinaki, M. Arenas et al., "Genetic basis of inosine triphosphate pyrophosphohydrolase deficiency," Human Genetics, vol. 111, no. 4-5, pp. 360-367, 2002.

[66] J. J. Biesele, "Some morphological effects of alkylating agents," Experimental Cell Research, vol. 9, supplement, pp. 525-534, 1963.

[67] J. C. Barrett, "Induction of gene mutation in and cell transformation of mammalian cells by modified purines: 
2-aminopurine and 6-N-hydroxylaminopurine," Proceedings of the National Academy of Sciences of the United States of America, vol. 78, no. 9, pp. 5685-5689, 1981.

[68] T. Tsutsui, H. Maizumi, and J. C. Barrett, "Induction by modified purines (2-aminopurine and 6-N-hydroxylaminopurine) of chromosome aberrations and aneuploidy in Syrian hamster embryo cells," Mutation Research, vol. 148, no. 1-2, pp. 107112, 1985.

[69] M. Behmanesh, K. Sakumi, D. Tsuchimoto et al., "Characterization of the structure and expression of mouse Itpa gene and its related sequences in the mouse genome," DNA Research, vol. 12, no. 1, pp. 39-51, 2005.

[70] S. An, R. Kumar, E. D. Sheets, and S. J. Benkovic, "Reversible compartmentalization of de novo purine biosynthetic complexes in living cells," Science, vol. 320, no. 5872, pp. 103-106, 2008. 

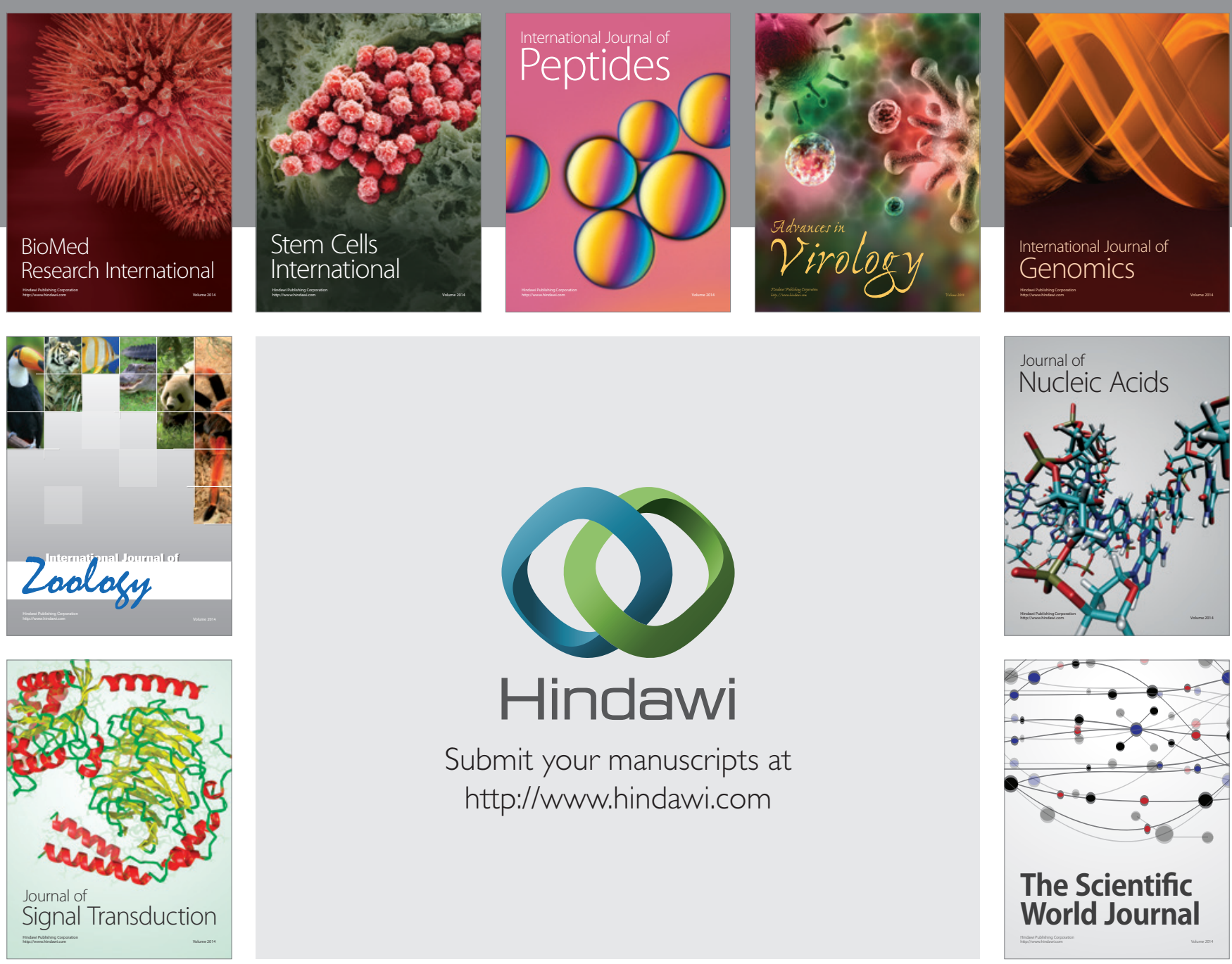

Submit your manuscripts at

http://www.hindawi.com
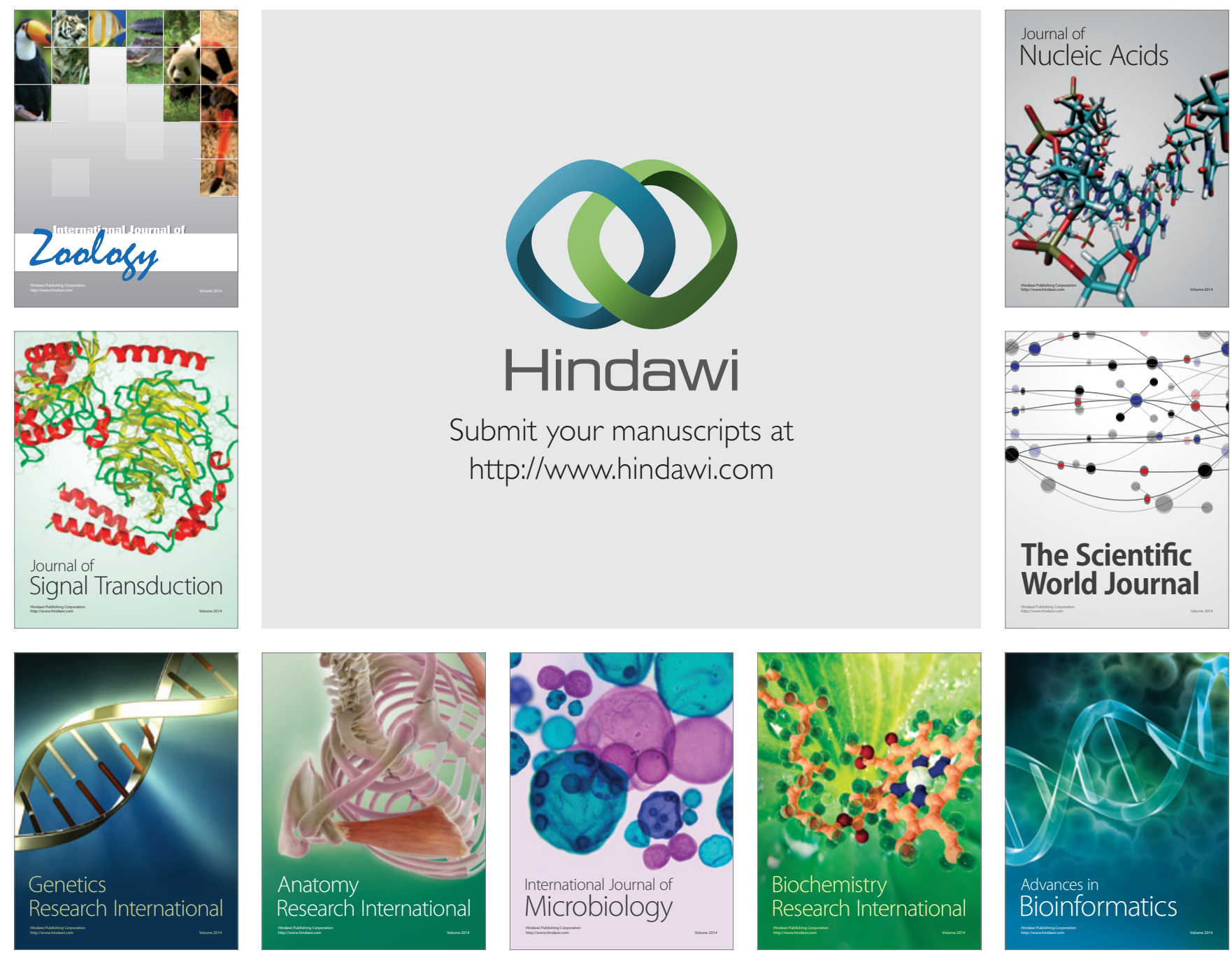

The Scientific World Journal
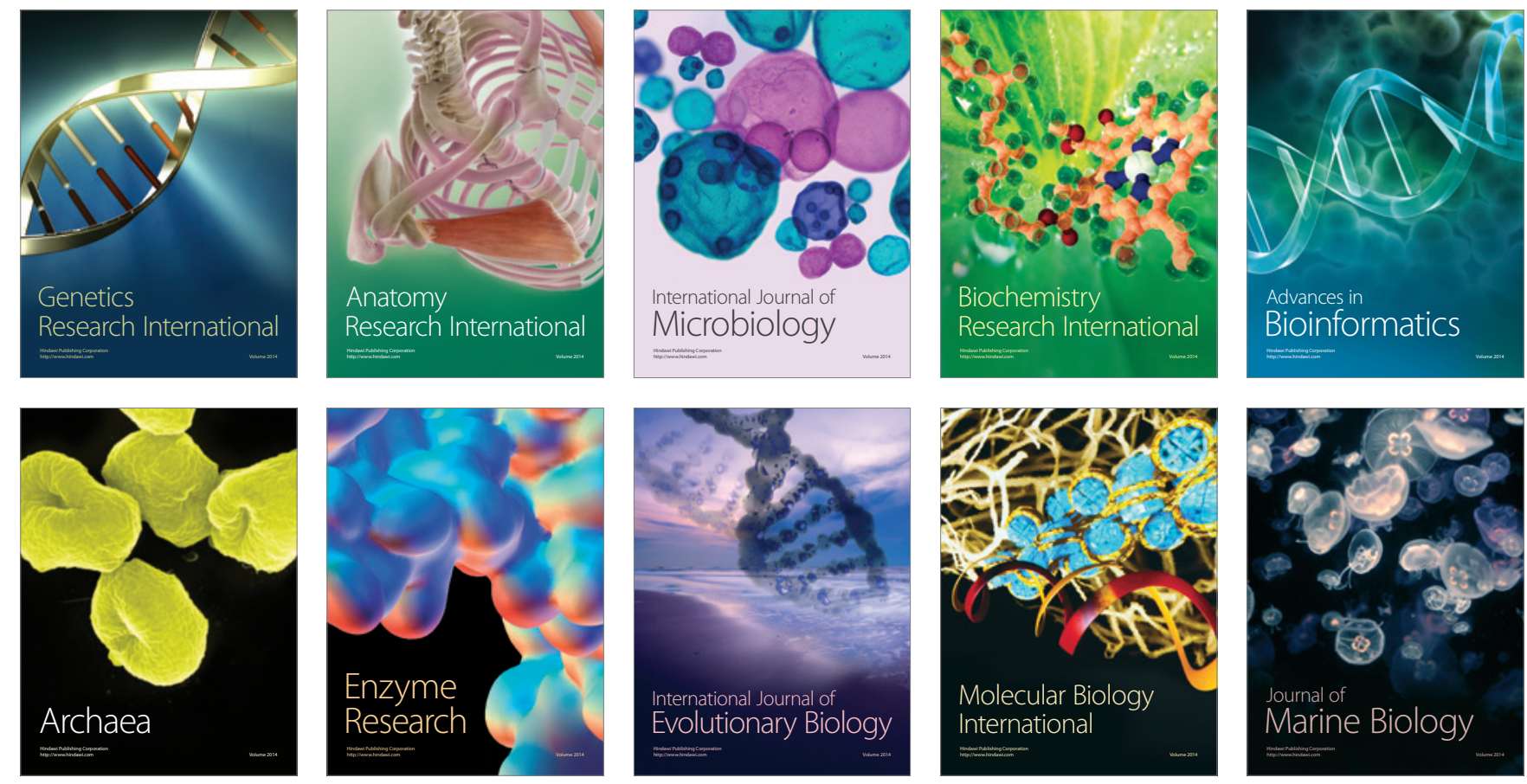